the encouragement and evaluation of legal information data base development, the setting up and operation of educational programs about computerized legal information retrieval for the legal profession, and the development of pilot schemes in the creation of data bases. A tax law data base has been announced as the first of such pilot schemes. For further information about the National Law Library, write to its offices at Inveresk House, 1 Aldwych, London, WC2ROHF, U.K.

In the meantime Mead Data Central, the producer of the LEXIS computerized legal information retrieval system in the United States, has announced the extension of LEXIS to English law.

The initial LEXIS English Library contains :

-English cases, reported in the Law Reports, All English Law Reports and Lloyd's Reports from 1945 to date.

-All tax cases reported in Simon's Tax Cases and Reports of Tax Cases.

In the near future LEXIS is also expected to add to the program a statutory library consisting of all general statutes and statutory instruments in force, a tax law library consisting of Inland Revenue press releases, extra-statutory concessions, and other tax-related documents, and an industrial law library.

In the United Kingdom LEXIS is offered by arrangement with Butterworth (Telepublishing) Ltd., and English lawyers have access to the complete LEXIS program, including all LEXIS files on American law. In the United States, the English files are available to all subscribers as a part of the regular service.

\title{
UNITED STATES LEGISLATION ON FOREIGN RELATIONS
}

The annual update volumes-Legislation on Foreign Relations Through 1979 have been published (Vol. I, February, 1980; Vol. II, March, 1980) as Joint Committee Prints of the House Committee on Foreign Affairs and the Senate Committee on Foreign Relations. These volumes contain current legislation and related executive orders. They are very valuable for scholars involved with or interested in foreign affairs. Vol. III, which contains treaties and was last published in 1977 is not being updated in the 1979 set. The volumes are published by the Government Printing Office in Washington, D.C.

\section{MULTINATIONAL CORPORATIONS : A NEW BIBLIOGRAPHY}

The Centre on Transnational Corporations at the United Nations in New York has published an over 400-page long, computer-produced 
Bibliography on Transnational Corporations. Somehow this publication has escaped notice. Perhaps it has not been adequately mentioned in sales lists and indexes despite, though in fact, it was published more than twelve months ago in 1979 and allocated a 1978 United Nations publication sales number (E/F.78.II.A.4).

The new bibliography is quite valuable in that it includes citations to official documents, monographs, journal articles, contributions, dissertations, and unpublished papers. As the legal control of transnational (or multinational) corporations is a relatively new subject having emerged as a discipline of scientific inquiry only in the early 1960's, the bibliography is supposed to be quite comprehensive. In fact, it contains over 4200 entries. It is arranged alphabetically by author or responsible issuing organization where there is no named author. There is a subject-index, but it is incomprehensible and inadequate. Researchers will either have to browse through the bibliography itself or depend on their memories of author names in order to find their reference sources.

Since its establishment in 1972, the United Nations Centre on Transnational Corporations has been busily engaged in publication of materials. Lists of these publications appear as annexes I and II to the Bibliography on Transnational Corporations, and they occupy twenty-five pages.

Bearing UNDEX classification number ST/CTC/4, the Bibliography on Transnational Corporations is priced at U.S. $\$ 24$.

New Periodical: The Company Lawyer, Vol. 1 (1980)

Oyez Publishing Limited, 11-13 Norwich Street, London, EC4A $1 \mathrm{AB}$, England, has commenced the publication of a new bi-monthly journal entitled The Company Lawyer. Arranged in several sections, the new journal contains short analytical articles and current update notes on developments in predominantly United Kingdom company law. However, there is also an international survey section (the first issue contains information about company (corporate) law developments in Australia, Brazil, Canada, Germany, Hong Kong, Japan, New Zealand, Singapore, South Africa, and the United States) as well as separate sections for case notes and book reviews.

The first issue has 64 pages. The annual subscription is $£ 48$. 